\title{
COMPARISON OF MICROBIAL INTERACTIONS OF ZINC OXIDE NANOMATERIALS IN VARIOUS SIZE AND SHAPE
}

\author{
1*David RUTHERFORD, '1Jaroslav JíRA, ${ }^{2}$ Júlia MIČOVÁ, ${ }^{3}$ Zdenek REMEŠ, ${ }^{4}$ Hua SHU HSU, \\ ${ }^{1}$ Bohuslav REZEK
}

${ }^{1}$ Faculty of Electrical Engineering, CVUT, Prague, Czech Republic, EU

2Institute of Chemistry, Institute of Chemistry SAS, Bratislava, Slovak Republic, EU

3Institute of Physics, CAS, Prague, Czech Republic, EU

${ }^{4}$ Department of Applied Physics, National Ping Tung University, Ping Tung, Taiwan

*david.rutherford@fel.cvut.cz

https://doi.org/10.37904/nanocon.2019.8666

\begin{abstract}
Zinc oxide nanoparticles ( $\mathrm{ZnO} \mathrm{NP}$ ) have shown great potential as a novel antibacterial material at a time when resistance towards conventional antibiotics is becoming more prevalent. We report bacteria inactivation by ZnO NP with novel hedgehog-like morphology using model gram-negative ( $E$. coli) and gram-positive ( $S$. aureus) bacteria. E. coli exposed to the novel $\mathrm{ZnO}$ hedgehog NP during growth resulted in 4 orders of magnitude reduction in viable cell concentration after $24 \mathrm{~h}$, which is more than 2 orders higher reduction compared to commercially available ZnO NPs with nominal sizes from $50 \mathrm{~nm}$ to $20 \mathrm{um}$. There was a positive correlation between hedgehog NP concentration and bacteria cell concentration reduction within the range tested $0.1-1.0 \mathrm{mg} / \mathrm{mL}$. S. aureus was less sensitive to ZnO NP exposure and inactivation effect of various $\mathrm{ZnO} \mathrm{NP}$, was comparable. The effect can be thus attributed to direct mechanical damage of the bacterial mebrane that is the most effective for the novel hedgehog ZnO NP. This conclusion was corroborated also by disk diffusion assays.
\end{abstract}

Keywords: Nanotechnology, microbiology, zinc oxide

\section{INTRODUCTION}

Materials at the nanoscale possess different physicochemical properties than bulk material due to increased surface area enhancing reactivity, and one such example is zinc oxide $(\mathrm{ZnO})$. A large body of literature exists for $\mathrm{ZnO}$ nanoparticles ( $\mathrm{ZnO} N P$ ) particularly in photovoltaics due to the materials semi-conductive properties, wide band gap and ultra-violet light absorption capability [1]. ZnO NP is also known to possess antibacterial properties and the mechanism of inactivation is thought to be an interplay between a number of different processes: nanoparticle morphology and surface charge interaction, physical contact between the nanoparticle surface and bacteria cell surface leading to permeabilisation, and reactive oxygen species (ROS) and zinc ion $\left(\mathrm{Zn}^{2+}\right)$ generation and subsequent internalisation that damages intracellular biomolecules such as DNA [2]. Reports suggest that $\mathrm{ZnO} N \mathrm{~N}$ treatment can even re-sensitize multi-drug resistant (MDR) bacteria to antibiotics that were previously ineffective [3]. Other promising antibacterial applications of $\mathrm{ZnO} N P$ include wound treatment [4], cancer therapy [5,6] and as an additive in food packaging [7]. The precise mechanism of interaction between $\mathrm{ZnO} \mathrm{NP}$ and biological cells is dependent on the unique physicochemical properties derived from the synthesis process.

ZnO NP can be synthesized via a number of different techniques: physical (e.g. gas plasma [8]), chemical (e.g. hydrothermal growth [9] or sol-gel technique [10]) or biological (extraction from plant tissue [11]). Each technique produces nanoparticles with unique morphologies with differing antibacterial potentials. ZnO NP characterization using microscopic and spectroscopic methods supplemented with standardized antimicrobial susceptibility testing is needed in order to compare the antibacterial potential of different $\mathrm{ZnO} N P$ due to the 
vast array of possible particle morphologies e.g. spherical, rod-like, wire-like, flower-shaped and tetrapod. Morphologies composed of rough surfaces and/or sharp, pointed projections could be well suited to bacteria cell inactivation through irreversible physical damage to the outer cell envelope. Functional groups on the $\mathrm{ZnO}$ NP surface result in ROS generation, accompanied by the release of zinc ions $\left(\mathrm{Zn}^{2+}\right)$ and internalisation further contributes to the inactivation mechanism.

The aim of this research was to investigate the antibacterial potential of ZnO NP synthesized with hedgehoglike morphology (i.e. many long, thin tubules branching from a single nucleation point). Bacteria were exposed to different concentrations of $\mathrm{ZnO}$ in liquid during growth, and the number of viable cells after certain timepoints over $24 \mathrm{~h}$ were recorded.

\section{METHODOLOGY}

\subsection{Bacteria Culture}

Gram-negative Escherichia coli (E. coli) and gram-positive Staphylococcus aureus (S. aureus) microorganisms were reconstituted using $200 \mathrm{~mL}$ Mueller Hinton broth (MHB, Oxoid) and grown overnight at $37^{\circ} \mathrm{C}$ in an orbital shaker (150 rpm, Biosan). $2 \mathrm{~mL}$ of this stock culture was added to $1 \mathrm{~mL}$ sterile glycerol and stored at $-20^{\circ} \mathrm{C}$ until required. A fresh culture was prepared for each experiment by inoculating $2 \times 1 \mathrm{~mL}$ of the thawed bacteria suspension onto 2 Mueller Hinton agar (MHA, Oxoid) plates and placed in incubator overnight at $37{ }^{\circ} \mathrm{C}$. Resultant growth was removed from one plate using a sterile loop and mixed with $5 \mathrm{~mL}$ MHB (relative $10^{\circ}$ dilution). Three decimal serial dilutions using MHB were performed and $2 \mathrm{~mL}$ of the final dilution was transferred to a sterile conical tube (Sterilin) and mixed with equal volumes of $\mathrm{ZnO}$ solutions. For the positive experimental control, $2 \mathrm{~mL}$ sterile deionized water $\left(\mathrm{dH}_{2} \mathrm{O}\right.$, conductivity $\left.(\sigma)=0.1 \mu \mathrm{S} / \mathrm{cm}\right)$ was added to bacteria instead of $\mathrm{ZnO}$ solution.

\subsection{Zinc oxide material synthesis \& preparation}

The synthesis procedure and extensive characterization of the hedgehog ZnO NP used in this study have been reported previously [9]. Briefly, crystalline ZnO NP were produced by adding equimolar volumes ( $25 \mathrm{mM}$ ) of zinc nitrate hexahydrate $\left(\mathrm{Zn}\left(\mathrm{NO}_{3}\right) 2 \cdot 6 \mathrm{H}_{2} \mathrm{O}\right)$ and hexamethylenetetramine (HMTA) at $90^{\circ} \mathrm{C}$ for $3 \mathrm{~h}$. Precursor salt residue was removed from the sample by washing 3-times with $\mathrm{dH}_{2} \mathrm{O}$ followed by centrifugation at 18,000 rpm (RCF: 23542g) for $20 \mathrm{~min}$. Spherical ZnO (Sigma) with an average size of $<50 \mathrm{~nm}$, and micronsized $\mathrm{ZnO}(20 \mu \mathrm{m})$ were used for comparison with the hedgehog $\mathrm{ZnO} N$. Stock solutions of $2 \mathrm{mg} / \mathrm{mL}$ were

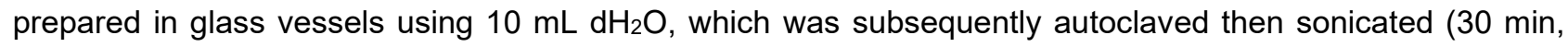
Sonorex Digitec, Bandelin) immediately before use.

\subsection{Antibacterial assessment techniques}

The bacteria-ZnO suspensions were placed upon an orbital shaker (150 rpm) located inside an incubator and samples were taken at various timepoints, up to $24 \mathrm{~h}$. Decimal serial dilutions were performed using sterile $0.9 \%$ sodium chloride solution ( $\mathrm{NaCl}$, Penta) and $1 \mathrm{~mL}$ of the dilutions were added to MHA plates in duplicate and placed in incubator. Images of the plates after 18-24h incubation were taken and the number of colonies on each plate was determined using ImageJ.

\section{RESULTS \& DISCUSSION}

\subsection{Viable cell concentration}

The number bacteria that remained viable and formed a colony on MHA after exposure to $\mathrm{ZnO}$ over an incubation time of $24 \mathrm{~h}$ can be viewed in Figures 1 and 2 . Bacteria not exposed to $\mathrm{ZnO}$ act as a control sample. 

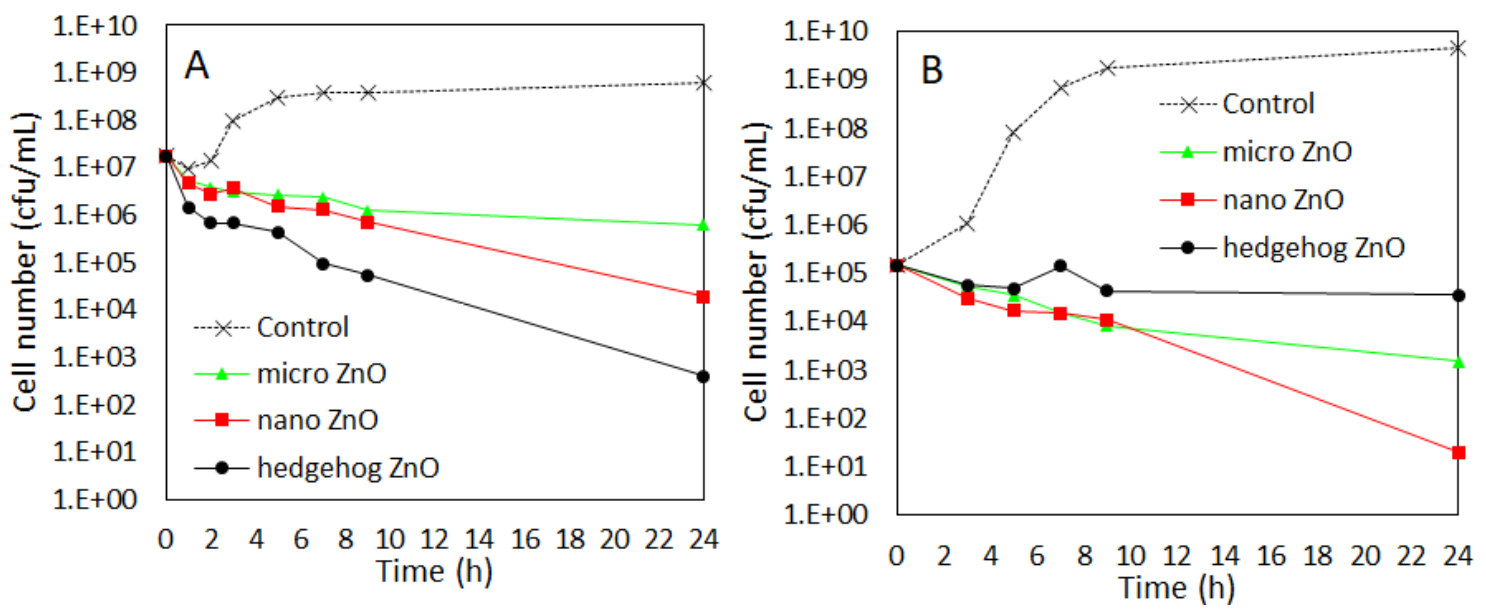

Figure 1 Number of viable $E$. coli cells after exposure to 3 types of $\mathrm{ZnO}$, micron-sized powder (micro $\mathrm{ZnO}$ ), nanopowder (nano $\mathrm{ZnO}$ ) and synthesised nanoparticles (hedgehog $\mathrm{ZnO}$ ) at $1 \mathrm{mg} / \mathrm{mL}(\mathrm{A})$ and $0.1 \mathrm{mg} / \mathrm{mL}(\mathrm{B})$.
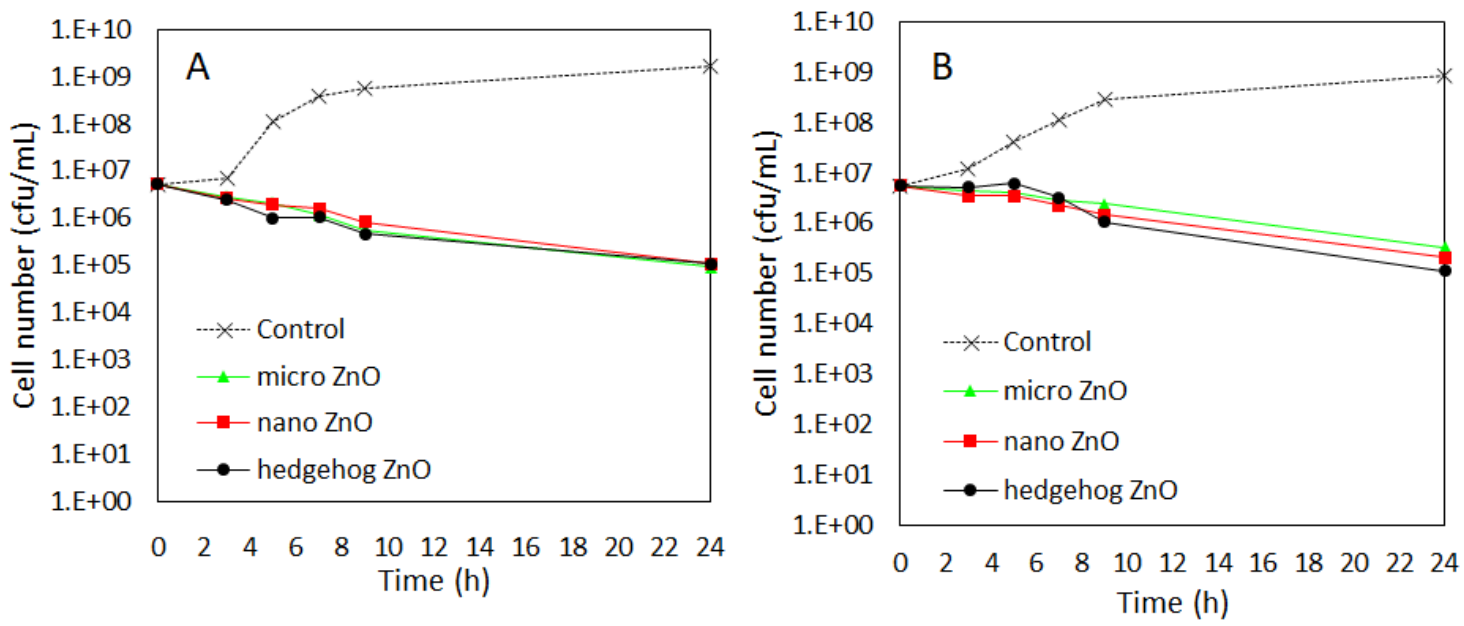

Figure 2 Number of viable $S$. aureus cells after exposure to 3 types of $\mathrm{ZnO}$, micron-sized powder (micro $\mathrm{ZnO}$ ), nanopowder (nano $\mathrm{ZnO}$ ) and synthesized nanoparticles (hedgehog $\mathrm{ZnO}$ ) at $1 \mathrm{mg} / \mathrm{mL}(\mathrm{A})$ and 0.1 $\mathrm{mg} / \mathrm{mL}(\mathrm{B})$.

For a concentration of $1 \mathrm{mg} / \mathrm{mL} \mathrm{ZnO,} \mathrm{gram-negative} E$. coli growth was inhibited to a greater extent than grampositive $S$. aureus (Figure $1 \mathrm{~A}$ and Figure $2 \mathrm{~A}$ ). In the case of $E$. coli, hedgehog $\mathrm{ZnO}$ NP showed the greatest antibacterial effect, resulting in approx. 4 orders reduction in viable cell concentration after $24 \mathrm{~h}$ compared to the untreated bacteria. The nano-sized reference material (nano $\mathrm{ZnO}$ ) inhibited growth by approx. 2.5 orders, and the micron-sized material (micro $\mathrm{ZnO}$ ) was the least effective at inhibiting $E$. coli growth. Interestingly, when a lower concentration of $0.1 \mathrm{mg} / \mathrm{mL} \mathrm{ZnO}$ was tested the hedgehog NP was the least effective compared to the other $\mathrm{ZnO}$ materials (Figure 1B).

There was no significant difference in the antibacterial potential of the $\mathrm{ZnO}$ materials tested against $\mathrm{S}$. aureus. The viable cell concentration was reduced by approx. 1.5 orders of magnitude compared to the untreated bacteria after $24 \mathrm{~h}$ for all $\mathrm{ZnO}$ material independent of concentration (Figures 2A and 2B). Thus, ZnO NP had generally a greater inhibitory effect against $E$. coli than against $S$. aureus.

The observed difference in bacterial inhibition efficacy of $\mathrm{ZnO}$ between the two bacteria types could be due to the fundamentally different outer cell structures. Gram-positive bacteria have a thick peptidoglycan layer located outside the phospholipid bilayer that enhances cell rigidity and makes cell death due to physical 
damage less likely. Gram-negative bacteria contain a much thinner peptidoglycan layer, as well as an additional phospholipid bilayer, resulting in a more fluid cell membrane which could be more prone to damage as a result of physical impact. This would explain the lower final cell concentration of $E$. coli cells compared with $S$. aureus after $24 \mathrm{~h}$ (Figures $1 \mathrm{~A}$ and $\mathbf{2 A}$ ). ZnO NP synthesised via the reaction between zinc nitrate and potassium hydroxide in ethanol achieved complete growth inhbition (8 orders reduction) of $E$. coli growth at a concentration of $200 \mu \mathrm{g} / \mathrm{mL}$, yet under the same experimental conditions $S$. aureus inhibition was not complete (4 orders reduction [12]). However, flow cytometric analysis of live and dead cells after ZnO NP exposure revealed little difference between the bacteria strains. In our study, the size and morphology of $\mathrm{ZnO}$ particulates had a greater inhibitory effect on $E$. coli than $S$. aureus, where hedgehog-like NP caused the largest reduction in viable cells after $24 \mathrm{~h}$ compared to the untreated cells, followed by spherical nano-sized material and then micron-sized particles (Figure 1A). There was little difference in $S$. aureus inhibition due to ZnO particle morphology (Figures $2 \mathrm{~A}$ and $\mathbf{2 B}$ ), again possibly due to the more rigid outer cell structure providing greater resistance to damage by physical impact. A study that used similar sized $\mathrm{ZnO}$ reference materials alongside synthesised $\mathrm{ZnO} N P$, albeit at a much lower concentration, reduced the viable cell concentration by 2 orders of magnitude regardless of particle size [13]. The synthesized NP resulted in a further 1 order of magnitude reduction in viable cells, and was equally effective against $E$. coli and $S$. aureus [13]. The nano-sized reference material had a structure with high crystalinity, whereas the synthesised NP had irregular shaped edges which indicated low surface crystalinity and increased surface defects attributed to oxygen or zinc vacancies in the crystal lattice structure [13]. The authors reported increased $\mathrm{Zn}^{2+}$ concentration using the synthesised NP compared with either reference material and proposed a mechanism of inactivation dependent on $\mathrm{Zn}^{2+}$ release from the NP surface due to the observed defects rather than ROS generation or physical NP-bacteria interaction [13].

\subsection{Disk diffusion assay}

Disk diffusion assay assesses the ability of an antibacterial solution to diffuse through agar and inhibit growth without coming into direct contact with the bacteria. For a concentration of $1 \mathrm{mg} / \mathrm{mL}$ we determined a zone of growth inhibition using $\mathrm{ZnO}$-loaded filter paper disks that were placed directly onto the agar surface containing bacteria. Limited inhibition was achieved against $S$. aureus yet none for E. coli. Spherical ZnO NP synthesised via a wet chemical method using zinc chloride and sodium hydroxide produced a larger zone of inhibition for S. aureus than E. coli [14]. By using different Zn-containing precursor molecules, the authors were able to synthesise nanorods and multi-faceted grain particles that also inhibited bacterial growth but to a lesser extent. Grain-like ZnO NP that were synthesized from plant extract also inhibited $S$. aureus growth more than E. coli, and a synergistic effect was observed when applied in conjunction with streptomycin [11]. These data suggest that NP size and morphology can affect the antibacterial effect of $\mathrm{ZnO}$.

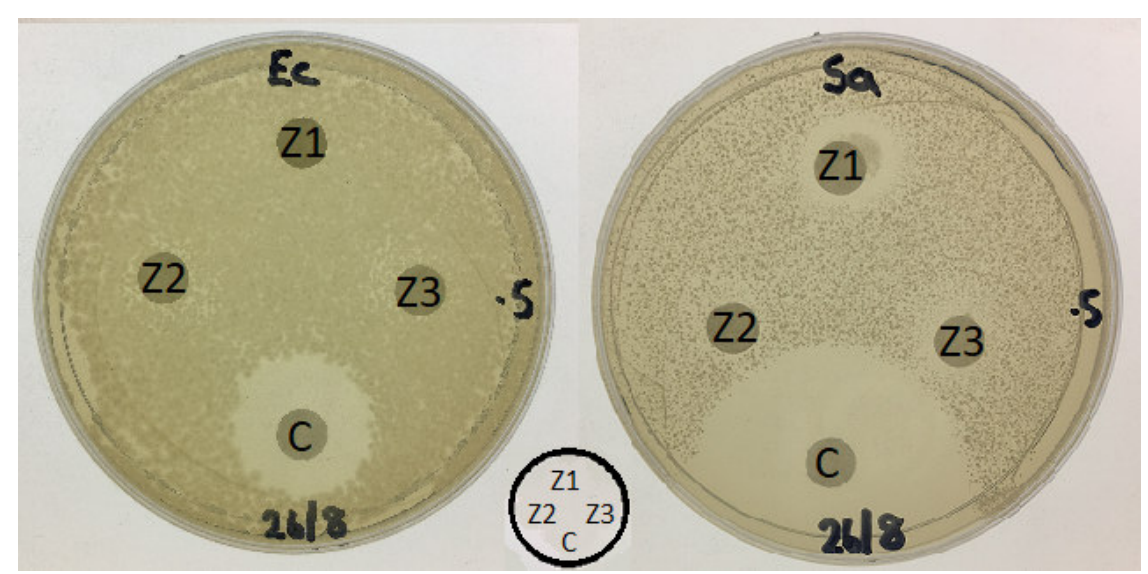

Figure 3 Images of bacteria on agar subjected to $\mathrm{ZnO}$-loaded filter paper disks (a - E. coli; b - S. aureus). Bacteria concentration on agar $=1 \times 10^{5} \mathrm{cfu} / \mathrm{mL}$. Inset plate layout displays positioning of disks and solutions: Z1 \& Z2 are hedgehog ZnO NP, Z3 is nanosized reference material and $\mathrm{C}$ is $25 \mu \mathrm{L}$ of $0.1 \mathrm{M} \mathrm{H}_{2} \mathrm{O}_{2}$. 


\section{CONCLUSION}

We studied antibacterial potential of $\mathrm{ZnO} N P$ with hedgehog-like morphology and comparison with commercially available nano-sized and micron-sized $\mathrm{ZnO}$ material. The hedgehog $\mathrm{ZnO} N \mathrm{NP}$ inhibited both $E$. coli and $S$. aureus growth. More pronounced effect was achieved using higher concentrations up to $1 \mathrm{mg} / \mathrm{mL}$. Both nano and micron-sized $\mathrm{ZnO}$ inhibited bacterial growth but to a lesser extent. E. coli was more sensitive towards hedgehog NP exposure than $S$. aureus when the interaction occurred in liquid with agitation. Growth inhibition was only observed when the NP directly interacted with the bacteria cell, which implies physical damage rather than chemical processes as the dominant mechanism underlying the antibacterial potential of hedgehog NP. These promising results provide evidence that $\mathrm{ZnO}$ NP shape is an important property which governs the antibacterial potential and $\mathrm{ZnO} N P$ with complex geometries such as the hedgehog-like particles could be used as an effective antibacterial treatment.

\section{ACKNOWLEDGEMENTS}

This work was supported by the GAČR (19-02858J), MOST (M-153-001-MY3, 107-2119-M-153-001) and by the Ministry of Education, Youth and Sport (CZ.02.1.01/0.0/0.0/16-019/0000778, CZ.02.2.69/0.0/0.0/16_027/0008465).

\section{REFERENCES}

[1] CHEN, Y. (2018). Review of ZnO Transparent Conducting Oxides for solar applications. IOP Conf. Ser.: Mater. Sci. Eng. 423012170.

[2] SiRELKhATIM, A., SEENI, A., MOHAMAD, D., HASAN, H., ANN, L. C., KAUS, N. H. M., MAHMUD, S. and BAKHORI, S. K. M. (2015). Review on Zinc Oxide Nanoparticles: Antibacterial Activity and Toxicity Mechanism. nml 7 219-42.

[3] JAN, T., IQBAL, J., ISMAIL, M., ZAKAULLAH, M., NAQVI, S. H. and BADSHAH, N. (2013). Sn doping induced enhancement in the activity of $\mathrm{ZnO}$ nanostructures against antibiotic resistant $\mathrm{S}$. aureus bacteria. Int $\mathrm{J}$ Nanomedicine 8 3679-87.

[4] KAUSHIK, M., NIRANJAN, R., THANGAM, R., MADHAN, B., PANDIYARASAN, V., RAMACHANDRAN, C., OH, D.-H. and VENKATASUBBU, G. D. (2019). Investigations on the antimicrobial activity and wound healing potential of ZnO nanoparticles. Applied Surface Science 479 1169-77.

[5] WAHAB, R., SIDDIQUI, M. A., SAQUIB, Q., DWIVEDI, S., AHMAD, J., MUSARRAT, J., AL-KHEDHAIRY, A. A. and SHIN, H.-S. (2014). ZnO nanoparticles induced oxidative stress and apoptosis in HepG2 and MCF-7 cancer cells and their antibacterial activity. Colloids and Surfaces B: Biointerfaces 117 267-76.

[6] SKALICKOVA, S., DOCEKALOVA, M., STANKOVA, M., UHLIROVA, D., RUTTKAY-NEDECKY, B., FERNANDEZ, C., KEPINSKA, M., MILNEROWICZ, H. and KIZEK, R. (2019). Zinc Modified Nanotransporter of Anticancer Drugs for Targeted Therapy: Biophysical Analysis.Available at https://www.ingentaconnect.com/content/asp/jnn/2019/00000019/000000005/art00005;jsessionid=5flpgke0jbluj.xic-live-02.

[7] ESPITIA, P. J. P., SOARES, N. DE F. F., COIMBRA, J. S. DOS R., DE ANDRADE, N. J., CRUZ, R. S. and MEDEIROS, E. A. A. (2012). Zinc Oxide Nanoparticles: Synthesis, Antimicrobial Activity and Food Packaging Applications. Food Bioprocess Technol 5 1447-64.

[8] JAIN, G., MACIAS-MONTERO, M., VELUSAMY, T., MAGUIRE, P. and MARIOTTI, D. (2017). Porous zinc oxide nanocrystalline film deposition by atmospheric pressure plasma: Fabrication and energy band estimation. Plasma Process Polym. 141700052.

[9] MIČOVÁ, J., BURYI, M., ŠIMEK, D., DRAHOKOUPIL, J., NEYKOVA, N., CHANG, Y.-Y., REMEŠ, Z., POPGEORGIEVSKI, O., SVOBODA, J. and IM, C. (2018). Synthesis of zinc oxide nanostructures and comparison of their crystal quality. Applied Surface Science 461 190-5. 
[10] LALlO DA SILVA, B., CAETANO, B. L., CHIARI-ANDRÉO, B. G., PIETRO, R. C. L. R. and CHIAVACCI, L. A. (2019). Increased antibacterial activity of $\mathrm{ZnO}$ nanoparticles: Influence of size and surface modification. Colloids and Surfaces B: Biointerfaces 177 440-7.

[11] GUPTA, M., TOMAR, R. S., KAUSHIK, S., MISHRA, R. K. and SHARMA, D. (2018). Effective Antimicrobial Activity of Green ZnO Nano Particles of Catharanthus roseus. Front Microbiol 9.

[12] CHOI, K.-H., NAM, K. C., LEE, S.-Y., CHO, G., JUNG, J.-S., KIM, H.-J. and PARK, B. J. (2017). Antioxidant Potential and Antibacterial Efficiency of Caffeic Acid-Functionalized ZnO Nanoparticles. Nanomaterials 7148.

[13] DE LUCAS-GIL, E., DEL CAMPO, A., PASCUAL, L., MONTE-SERRANO, M., MENÉNDEZ, J., FERNÁNDEZ, J. F. and RUBIO-MARCOS, F. (2019). The fight against multidrug-resistant organisms: The role of ZnO crystalline defects. Materials Science and Engineering: C 99 575-81.

[14] GETIE, S., BELAY, A., REDDY CHANDRA, A. and BELAY, Z. (2017). Synthesis and Characterizations of Zinc Oxide Nanoparticles for Antibacterial Applications. J Nanomed Nanotechnol s8. 